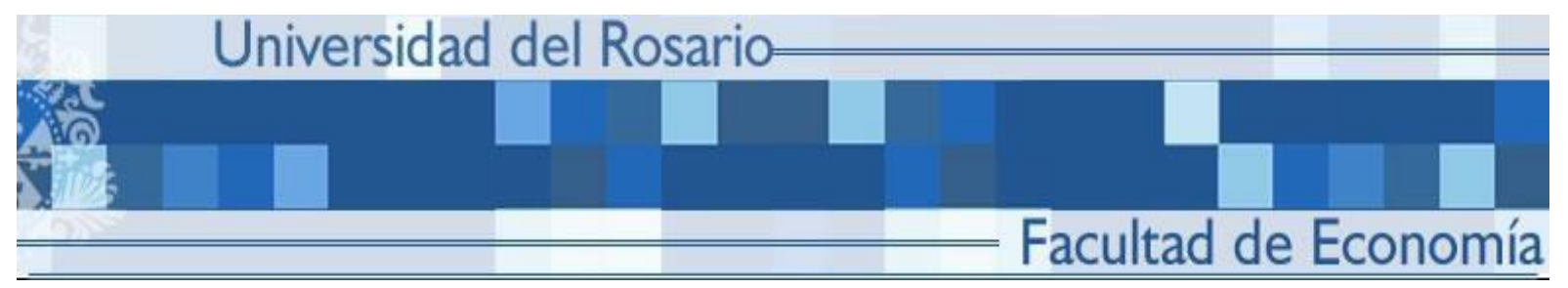

End-Of-Conflict Deforestation: Evidence From Colombian's Peace Agreement

Mounu Prem

Santiago Saavedra

Juan F. Vargas

SERIE DOCUMENTOS DE TRABAJO

No. 226

Diciembre de 2018 


\title{
END-OF-CONFLICT DEFORESTATION: EVIDENCE FROM COLOMBIA'S PEACE AGREEMENT
}

\author{
MOUNU PREM ${ }^{\ddagger}$, SANTIAGO SAAVEDRA* $^{\star}$ AND JUAN F. VARGAS
}

This version: December 2018

\begin{abstract}
Armed conflict can endanger natural resources through several channels such as direct predation from fighting groups, but it may also help preserve ecosystems by dissuading extractive economic activities through the fear of extortion. The effect of conflict on deforestation is thus an empirical question. This paper studies the effect on forest cover of Colombia's recent peace negotiation between the central government and the FARC insurgency. Using yearly deforestation data from satellite images and a difference-in-differences identification strategy, we show that areas controlled by FARC prior to the declaration of a permanent ceasefire that ultimately led to a peace agreement experienced a differential increase in deforestation after the start of the ceasefire. The deforestation effect of peace is attenuated in municipalities with higher state capacity, and is exacerbated by land intensive economic activities. Our results highlight the importance of complementing peacemaking milestones with state building efforts to avoid environmental damage.
\end{abstract}

JEL CODES: D74, Q34

Keywords: Deforestation, Conflict, Peace building, Colombia

We would like to thank Ana María Ibañez, Rachid Laajaj, and seminar participants at the Sustainability and Development Conference and Rosario-Andes Taller Applied (RATA). Andrés Rivera and Carolina Velez provided outstanding research assistance.

${ }^{\ddagger}$ School of Economics, Universidad del Rosario. E-mail: francisco.munoz@urosario.edu.co.

${ }^{\star}$ School of Economics, Universidad del Rosario. E-mail: santiago.saavedrap@urosario.edu.co.

ฯ School of Economics, Universidad del Rosario. E-mail juan.vargas@urosario.edu.co. 


\section{INTRODUCTION}

Deforestation is a pressing threat to life. It is estimated that over $15 \%$ of all greenhouse gas emissions, which contribute substantially to the ongoing patterns of climate change, are the result of man-made deforestation. ${ }^{1}$ Almost 19 million acres of forest are lost every year, an area roughly equal to the land size of South Carolina. ${ }^{2}$ Deforestation patterns are especially worrisome in tropical rainforests which host most of the world's biodiversity. In the Amazon only, almost a fifth of forest cover has been lost in the last 50 years, and tropical deforestation emissions are larger than those of the entire European Union (Seymour and Busch, 2016).

By and large, deforestation takes place to make land available for alternative uses, including farming, cattle ranching, and urban sprawl. However, more fundamental causes of deforestation, such as the political economy drivers of economic exploitation, have been less studied. Take the case, for example, of the effect of conflict on deforestation. As about $40 \%$ of tropical forests are located in countries with violent conflict (CIFOR, 2018), studying how violence can exacerbate, attenuate, or reverse secular deforestation trends is of foremost importance.

Conflict and deforestation can be related in several ways. On the one hand, conflict can reduce deforestation if armed groups use forest coverage to hide (Fearon and Laitin, 2003), or if investors fear the potential extortion that violent groups could exert on their businesses (Camacho and Rodriguez, 2013). On the other hand, conflict can increase deforestation if the nature of economic activities used by armed groups to fund their operation and 'cause' are land-intensive. This is for instance the case of illegal crops such as coca or poppy, or the exploitation of natural resources. ${ }^{3}$ This implies

\footnotetext{
${ }^{1}$ See https://www.worldwildlife.org/threats/deforestation (last accessed December 1st, 2018).

${ }^{2}$ Ibid.

${ }^{3}$ This would be an example of the resource curse argument (Auty, 1993) applied to deforestation. See Ross (2012) for a thorough review about the resource curse.
} 
that the effect of conflict on deforestation is ultimately an empirical question, and can vary depending on the context.

In this paper, we contribute to the literature on the political causes of economic-driven deforestation by studying the effect of the recent peace process in Colombia on forest cover. Using a difference-in-differences empirical strategy, we find the permanent ceasefire declared by the Revolutionary Armed Forces of Colombia (FARC from the Spanish acronym) was followed by a large increase in deforestation in municipalities formerly controlled by the armed group, relative to other areas.

The ceasefire was declared on December 20 of 2014 and constituted one of the main milestones of the four-year long peace process that started in October 2012. Because it was largely met, it signaled a credible commitment by FARC to lay down their weapons. On August 29 of 2016 FARC and the government reached a definitive bilateral ceasefire and later that year the final peace agreement was signed by both parties, putting an end to a five-decade long conflict. While the agreement is probably the most important political achievement of modern Colombia, it also created important unintended costs, such as the killing of social leaders (Prem et al., 2018) and the surge in deforestation which we highlight in this paper.

We explore potential heterogeneous effects according to a number of pre-ceasefire municipal characteristics and exploit within municipality variation in institutional presence (in the form of protected national parks, which are more intensely monitored than other forest areas) to conclude that the increase in deforestation is attenuated in municipalities with higher state capacity. We also find that the increase in deforestation is mainly driven by patterns of massive deforestation, those occurring in large areas as opposed to smaller isloated patches.

This is consistent with an interpretation in which conflict-driven armed group presence 
prevented the occurrence of land intensive economic activities, and that these business are responsible for the reduction in forest cover when the ceasefire provides the opportunity. ${ }^{4}$ This is, however, attenuated when state institutions can regulate and oversee exploitation. These results highlights the importance of complementing peacemaking milestones with state building efforts and good governance to avoid environmental damage.

As mentioned, the literature looking at the effect of conflict on deforestation is scarce. ${ }^{5}$ Two exceptions are Burgess et al. (2015) and Fergusson et al. (2014). The former studies the effect of Sierra Leone's civil war on deforestation and finds that conflict-prone municipalities experienced less deforestation during the fighting. The latter shows that the paramilitary expansion in Colombia during the first part of the 2000s generated large increases in deforestation at the municipal level. Our paper differs to both in that we study the deforestation incentives of the end of a conflict. ${ }^{6}$ Moreover, while our results are aligned with those of Burgess et al. (2015) -in that conflict acts as a brake on deforestation-, they differ from those of Fergusson et al. (2014). We conclude that the deforestation effects of conflict are most likely context-specific. ${ }^{7}$ Finally our paper also contributes to the literature studying the relationship between state capacity and economic development (see for example Besley and Persson, 2014 and Acemoglu et al., 2015), by showing how state capacity diminishes the risk of deforestation in areas previously controlled by FARC after the start of the ceasefire.

\footnotetext{
${ }^{4}$ As a further validation of this, we find that the increase in deforestation is larger in places more exposed to cattle ranching (which is land intensive), but in places suitable for coca cultivation (which is not).

${ }^{5}$ The opposite causal relationship, from environmental degradation and climate change to conflict, has been much more studied. Dell et al. (2014) provide a recent comprehensive review.

${ }^{6}$ Our data is also richer as it is constituted by a yearly panel of deforestation and there are ten times more municipalities in Colombia than in Sierra Leone.

${ }^{7}$ Other related literature highlights the political incentives of deforestation. While Burgess et al. (2012) study the interaction between the incentives of local bureaucrats and the institutional constraints to reduce deforestation, Saavedra and Romero (2018) focus on the relationship between communal land titling and deforestation.
} 
The remainder of the paper is organized as follows: Section 2 presents details of Colombia's armed conflict and deforestation patterns. Section 3 describes the data sources and measurement. Section 4 discusses our empirical strategy to estimate the causal effect of the end of conflict on deforestation. Section 5 reports our main results, robustness tests and potential mechanisms. Finally, section 6 concludes.

\section{Context}

2.1. Colombia's conflict and the peace process. Colombia's civil conflict started with the foundation of left-wing guerrillas FARC and the National Liberation Army (ELN from the Spanish acronym) in the mid 1960s. Guerrillas claim to represent the rural poor and have fought for over 50 years with the stated aim of overthrowing the government. In order to finance the protracted war, both groups have been profiting from several forms of illegal activities localized within the Colombian territory (Richani, 1997). This implies that sub-national territorial dominance is an important intermediate objective of the armed groups.

The conflict was a Cold War proxy until the end of the 1980s, but escalated during the 1990s fueled by the involvement of the guerrillas in illegal drug trafficking and the consolidation of right wing paramilitary groups. In the mid 1990s, the paramilitaries effectively became a third force in the conflict, when splintered paramilitary armies colluded under the umbrella organization of the United Self-Defense Groups of Colombia (AUC by its Spanish acronym). The 5-decade long, three-sided Colombian conflict resulted in over 8.5 million people are formally registered with the state as victims of the conflict. ${ }^{8}$

\footnotetext{
${ }^{8}$ Source: Victims' Registry, from the Unit for the Victims Assistance and Reparation, March 2018
} figure (https://www. unidadvictimas.gov.co/en). 
On October 2012 the Colombian government and FARC started peace negotiations in Cuba. While the four-year long process was characterized by constant ebb and flow, one of the most significant milestones was the establishment of a permanent ceasefire by FARC on December 20, 2014. In fact, as a result of the ceasefire, FARC withdrew their troops to more remote areas where military contact with government security forces and other armed groups was unlikely to take place. This explains why FARC's offensive activities drop by $98 \%$ during this period (CERAC, 2016). ${ }^{9}$

In this paper, we show that FARC's inability to respond violently during the ceasefire (which was largely met until followed by the bilateral definitive ceasefire and then by the final disarmament in 2016) constituted a window of opportunity for investors to carry out economic activities in previously FARC-dominated areas that increased deforestation.

2.2. Deforestation in Colombia. Around $30 \%$ of the world's land is covered with forest. Colombia contributes to global forests more than proportionally relative to the country's total area. Over half of the country (around 150 million acres) is covered by forests (Ministerio de Ambiente, 2017). However, Colombia has deforested rather rapidly. During the period 1990-2016 deforestation amounted to over 15 million acres. And during 2017 it reached almost 550 thousand acres. ${ }^{10}$ Overall, the country's ambitious goal of "zero deforestation" by 2030 seems today hard to achieve. ${ }^{11}$

While most of the population in Colombia is concentrated in the central region, during the course of the $20^{\text {th }}$ century internal frontier colonization processes pushed large numbers of people to the peripheral regions hosting most forests (see Figure 1). By

\footnotetext{
${ }^{9}$ The final peace agreement was endorsed by Congress on November 30th, 2016 after a previous version of it got rejected by a $0.5 \%$ vote margin in a referendum that took place on October $2^{\text {nd }}$ that year.

${ }^{10}$ Source: http://smbyc.ideam.gov.co/MonitoreoBC-WEB/pub/reporteGeoproceso.jsp?id_ reporte $=6891$ (last accessed 12/13/2018).

${ }^{11}$ See https://sostenibilidad.semana.com/medio-ambiente/articulo/ cero-deforestacion-para-2020/38654 (last accessed 12/13/2018) for a description of the government's deforestation reduction plans.
} 
the late 1980s, most of the remaining colonization flows were driven by the presence of illegal armed groups and the expansion of illicit crops (Etter et al., 2006).

The last two decades have witnessed several (legal and illegal) drivers of deforestation in Colombia. The main force is pasturing, which takes around 500 thousand acres of forest per year. Mining accounts for around 60 thousand acres of deforestation per year and illegal crops reduce forest cover in about 37 thousand acres (UNODC, 2016). Other drivers include infrastructure building, illegal logging and the expansion of agro-industry businesses, notably oil palm growing. In terms of land use, half of the deforested areas were converted to grasslands, while only $7 \%$ were dedicated to cultivation (Yepes and González, 2018).

In this paper we assess the extent to which the permanent ceasefire declared by FARC on December 2014 and the subsequent signature of the peace agreement exacerbated or attenuated deforestation in Colombia. Given the largely documented cases of FARC banning logging and other economic activities (Dávalos, 2001), we posit that FARC's halt of activities generated incentives for private investors to set up business in FARCcontrolled regions, thereby exacerbating deforestation. This phenomenon should also be more prevalent in areas with little institutional capacity to control and regulate this process. $^{12}$

\section{DATA}

We combine data from different sources in order to build a municipality-year level panel to study the effect of the permanent ceasefire on deforestation. Our analysis covers the period from 2011 to 2017, since the start of the presidential term of Juan Manuel

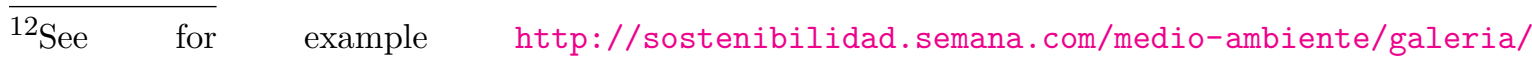
la-macarena-asi-estan-destruyendo-a-este-parque-natural/34958 (last accessed $12 / 01 / 2018)$.
} 
Santos, who initiated peace negotiations with FARC in 2012. ${ }^{13}$ Our sample includes 1,051 municipalities with a population of less than 200,000. We drop state capital and other major cities as these are both largely urbanized and less affected by the conflict. ${ }^{14}$ We now describe the main variables we use in the analysis as well as their sources.

3.1. FARC presence. To construct a measure of FARC presence, we use the violence dataset originally compiled by Restrepo et al. (2004), and updated through 2014 by Universidad del Rosario. This dataset codes violent events recorded in the Noche $y$ Niebla reports from the NGO Centro de Investigación y Educación Popular (CINEP) of the Company of Jesus in Colombia, which provides a detailed description of the violent event, date, the municipality in which it occurred, the identity of the perpetrator, and the count of victims involved in the incident. ${ }^{15}$

We create a dummy for $F A R C$ presence if there was at least one event perpetrated by FARC in the period 2011-2014, after president Juan Manuel Santos took office and before the beginning of the ceasefire. Based on our definition we define 130 municipalities (12\% of our sample) as having FARC presence before the ceasefire (see Table 1).

Measuring the influence exercised by an armed group over a specific location is extremely challenging. Indicators of presence and non-violent coercion over a large set of municipalities cannot be systematically recorded in an objective way. Violence, on the other hand, while more easily observed, is only imperfectly correlated with territorial dominance. However, non-violent dominance is unlikely to occur without any violence inflicted in the past, either as a way to legitimize influence with the citizenry or to

\footnotetext{
${ }^{13}$ Santos was ultimately awarded the Nobel Peace Prize in 2016 "for his resolute efforts to bring the country's more than 50-year-long civil war to an end."

${ }^{14}$ Our results are robust to using all the country's municipalities.

${ }^{15}$ Noche y Niebla sources include "1. Press articles from more than 20 daily newspapers of both national and regional coverage. 2. Reports gathered directly by members of human rights NGOs and other organizations on the ground such as local public ombudsmen and, particularly, the clergy." (Restrepo et al. 2004, p. 404). Notably, since the Catholic Church is present in even the most remote areas of Colombia, we have extensive coverage of violent events across the entire country.
} 
oust any contesting (legal or illegal) group. It is thus reasonable to assume that the ability to inflict localized violence over a relatively long period could be expected to translate into influence in different ways. We thus follow a growing empirical literature on the Colombian conflict (see e.g. Ch et al., 2018; Acemoglu et al., 2013; Fergusson et al., 2018), and use past violence over a period of years as an (imperfect) indicator of influence. ${ }^{16}$

3.2. Deforestation data. We measure deforestation using the Global Forest Change dataset, which measures forest change globally between 2000 and 2017 (Hansen et al., 2013). These data were created with remote-sensing techniques, using satellite LANDSAT's images with a resolution of $30 m \times 30 m$ per pixel. Given the use of satellites, missmeasurement due to conflict is not a concern. The authors define "tree cover" as all vegetation higher than 5 meters of altitude, irrespective of the canopy density. Deforestation (or tree cover loss) is coded as the complete removal of tree cover canopy at the pixel level from one year of measurement to the other.

We aggregate these data at the municipal level using all the pixel that fall within a municipality area. ${ }^{17}$ Our main measure of deforestation is thus defined as the deforested area in a given municipality/year relative to the entire forest area of that municipality in 2000, the first year for which Hansen et al. (2013) provide data. ${ }^{18}$

Deforestation patterns may be driven, on the one hand, by extensive agricultural activities or large areas devoted to grazing. On the other, they may result from smallholding or subsistence agriculture. While the former type of drivers are consistent with the

\footnotetext{
${ }^{16}$ Arjona and Otálora (2011) compare existing databases of civil war violence in Colombia to survey evidence on armed groups' presence (for the small subsample of municipalities for which the latter is available) and conclude that while violence is likely to underestimate -by roughly the same magnitudeboth guerrilla and paramilitary control, there is a non-negligible correlation between both measures. ${ }^{17}$ Pixels that land on municipal borders are assigned according to the municipal pixel share.

${ }^{18}$ As a robustness we show results for two other measures. The deforested area in a municipality/year divided by the total forest coverage of the previous year, and the log of the deforested area in a municipality/year.
} 
investment interests of large agro-industrial businesses, the latter may result from formerly dispossessed or forcibly displaced peasants returning to their land by taking advantage of the ceasefire and the subsequent security improvements. We are thus interested in distinguishing between "massive" or "granular" deforestation patterns. To that end, we add contiguous deforested pixels into polygons.

The area of these polygons at the end of the study period (2017) allows us to define massive and granular deforestation. In particular, we use a cutoff of 11 pixels $(\approx 1$ hectare or 2.5 acres) so that any polygon (made of continuous pixels) of cumulative deforestation equal or larger (smaller) than one hectare is considered massive (granular) deforestation. We asses the robustness of the results to defining the cutoff for massive deforestation at two hectares or half an hectare.

Once we have the picture of cumulative deforestation at the end of the sample period, distinguishing massive from granular pixels, we can then back up through the previous years to code each deforested pixel/year as either granular or massive depending on the final (2017) polygon that contains it. A hypothetical example can be seen in Figure 2. The $5 \times 5$ top grid is composed by 25 pixels as coded in 2017 . The green pixels are covered by forest and the white pixels are deforested. The number written on the latter corresponds to the year in which deforestation took place. The bottom two grids report how deforestation in each pixel of the top grid is coded in 2015. Even though both patches of deforestation in 2015 are of size two pixels (i.e. $1,800 \mathrm{~m}^{2}$ ), the one on the left grid is classified as granular, and the one on the right is massive. This because the neighboring deforested pixels on the bottom left panel will not be deforested later (up to the end of our sample period). In contrast, the deforested patch on the bottom right panel will grow larger on later years, reaching in 201712 contiguous deforested pixels (i.e. $10,800 m^{2}>1$ hectare). ${ }^{19}$

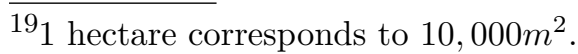


Our data on deforestation reveal that Colombia is a country with a vast coverage of forest, on average half of the area of a municipality is covered by forest. However, on average $0.5 \%$ of the forest area becomes deforested on a given year (see Table 1 ). The cumulative share of deforestation during the ceasefire period is mapped in Figure 3. The largest deforestation took place in the Caribbean region, in the northern part of the country (specifically in the departments of Sucre, Bolivar and Magdalena), as well as by the border with Venezuela, in the northeast (especially in Norte de Santander and Arauca). ${ }^{20}$ The Amazon basin in the southeast, and the Pacific region on the west-most belt, are the least deforested regions between 2015 and 2017.

When we split the evolution of deforestation during our entire sample period (2011 to 2017) by municipalities with and without FARC presence, we observe that the two series track one another pretty closely prior to the start of the ceasefire (see figure 4). In contrast, during the ceasefire period (starting in 2015) a wedge is created between the two. Despite the fact that both series increase, deforestation in areas formerly controlled by FARC increases much more rapidly. That the gap is increasing overtime is consistent with the fact that, above and beyond the ceasefire, during the implementation stage of the peace agreement (2017), FARC actually moved away from its strongholds to concentrate in areas that were agreed with the government to start the reincorporation process of former combatants. The next section describes how we explore this heterogeneous time effect more formally.

3.3. Other datasets. We complement these data with a set of municipality-level characteristics from different sources. This information includes a measure of state presence that uses the average number of public offices of in each municipality as in Acemoglu et al. (2015), to define a dummy that equals one for places above the median of the empirical distribution. We use a measure of military presence defined as the log of the

\footnotetext{
${ }^{20}$ Colombia is divided in 32 inland departments. These are equivalent to U.S. states.
} 
distance of each municipality centroid to the closest military unit with at least 3,000 soldiers.

We use Mejia and Restrepo (2015)'s measure of coca soil and climate suitability at the municipality level. ${ }^{21}$ Specifically, we define a dummy that equals one for municipalities above the median of the empirical coca suitability distribution. Finally we define a municipality as being intensive in cattle ranching if the total number of cattle livestock per hectare is above the median. To that end, we use the 2014 national agricultural census, the first one carried out in Colombia since the $1970 \mathrm{~s}^{22}$

We also use within-municipality variation on the presence of National Parks. National parks are protected areas established to preserve native ecosystems and species. We posit that, relative to other areas within the same municipality, plots that lie within a national park are less likely to be deforested all else equal. This is because of the presence of monitoring mechanisms that are designed and implemented by the national government, irrespective of municipal-specific conditions that make deforestation more or less likely. We created this measure by overlaying geo-referenced information of the boundaries of national parks with the deforestation measures described above. ${ }^{23}$

\section{EMPIRICAL STRATEGY}

Our identification strategy exploits the timing of the permanent ceasefire announced by FARC on December 20, 2014, as well as the spatial distribution of the presence of FARC across municipalities prior to the ceasefire. More formally, using the subindex $m$

\footnotetext{
${ }^{21}$ Coca is used to produce cocaine, and Colombia is the world's top exporter of this illegal alkaloid.

${ }^{22}$ Extensive grazing systems are one of the main drives of deforestation, particularly in latin America. In this region, most of the deforestation that has taken place since the 1990s owes to the expansion of pastures for livestock production. In addition to deforestation, cattle ranching causes environmental damage by releasing billions of tonnes of carbon dioxide into the atmosphere (see FAO's Livestock Policy Brief 03, available from http://www.fao.org/3/a-a0262e.pdf (last accessed 12/16/18).

${ }^{23} \mathrm{~A}$ shape file containing all the national parks of Colombia can be downloaded from the website of the parks authority: www.parquesnacionales.gov.co (last accessed 12/17/2018).
} 
to denote municipalities, $d$ to denote departments, and $t$ to denote time, we estimate the following difference-in-differences model: ${ }^{24}$

$$
y_{m d t}=\alpha_{m}+\lambda_{d t}+\beta_{1}\left(\text { Cease }_{t} \times F A R C_{m}\right)+\varepsilon_{m d t}
$$

Our outcome of interest, $y_{m d t}$, is the share of the deforested area in municipality $m$ of department $d$ and in time $t$, relative to the total municipal forest coverage in 2000, the first year in which the pixel-level forest data of Hansen et al. (2013) is available. ${ }^{25}$ $F A R C_{m}$ is a dummy that equals one for municipalities with FARC presence as measured before the ceasefire, and Cease $e_{t}$ is a dummy that equals one after the start of the permanent ceasefire (i.e. since 2015). $\alpha_{m}$ and $\lambda_{d t}$ are municipality and department/time fixed effects that capture any time-invariant municipal-level heterogeneity and any aggregate department-level time shock, respectively. The error term $\varepsilon_{m d t}$ is clustered at the municipality level.

All regressions are weighted by the forest coverage in 2000. In this way we give the same weight to every forest area irrespective of the size of the municipality, and hence the parameter of interest can be interpreted as the causal effect of the ceasefire on deforestation in the area covered with forest in 2000, not in the entire municipality. Our results are, however, robust to not using this weighting strategy.

Our coefficient of interest, $\beta_{1}$, captures the differential change (before and after the ceasefire) in municipalities with FARC presence relative to municipalities with no FARC presence, taking into account any differential effects driven by fixed municipality characteristics over time and any time shocks that could affect departments differently. The main identification assumption is that, in the absence of the ceasefire, the deforestation in municipalities with FARC presence would have evolved in a similar fashion than the deforestation in municipalities with no FARC presence.

\footnotetext{
${ }^{24}$ Colombia has 1,118 municipalities distributed in 33 departments.

${ }^{25}$ As explained in section 3 , our results are robust to using other definitions of the dependent variable.
} 
The validity of this "parallel trends" assumption can be assessed by estimating the following dynamic version of (4.1):

$$
y_{m d t}=\alpha_{m}+\lambda_{d t}+\sum_{j \in T} \beta_{j}\left(F A R C_{m} \times \delta_{j}\right)+\epsilon_{m d t}
$$

where $T$ includes all years of our sample period but 2014, which is the year right before the ceasefire. ${ }^{26}$ The parameters $\beta_{j}$ can be interpreted as the deforestation in municipalities with FARC presence compared to non FARC municipalities, relative to the year right before the ceasefire (2014).

4.1. Other specifications. We estimate two different set of equations to better understand the potential mechanisms behind our results. First, we augment the main specification in equation (4.1) to test for heterogeneous effects in places that are more attractive for deforestation or where this activity is likely more costly. We do so by adding a third interaction term. Let the municipality characteristic $Z_{m}$, measured before the ceasefire, be a proxy of the relative attractiveness/cost of deforestation. We estimate:

$$
\begin{aligned}
y_{m d t} & =\alpha_{m}+\lambda_{d t}+\beta_{1}\left(\text { Cease }_{t} \times F A R C_{m} \times Z_{m}\right)+\beta_{2}\left(\text { Cease }_{t} \times F A R C_{m}\right) \\
& +\beta_{3}\left(\text { Cease }_{t} \times Z_{m}\right)+\mu_{m d t}
\end{aligned}
$$

Our coefficient of interest, $\beta_{1}$, captures the differential deforestation in places with FARC presence and with municipality characteristic $Z_{m}$. More specifically, we assess potential heterogeneous effects given by municipal-level proxies of institutional state presence, military presence, coca suitability, and presence of cattle ranching. We have described these variables in section 3 .

Second, as discussed in section 3, we exploit within municipality variation on the extent of deforestation (granular versus massive), as well as inside and outside protected ${ }^{26}$ We omit this year to avoid perfect collinearity. 
national parks. To this end, we add one dimension to our panel. Let $H_{c}$ denote withinmunicipality areas experiencing granular/massive deforestation or inside/outside a national park. We estimate:

$$
y_{c m d t}=\alpha_{c m}+\lambda_{m t}+\delta_{c t}+\beta_{1}\left(H_{c} \times \text { Cease }_{t} \times F A R C_{m}\right)+\omega_{m d t}
$$

Our coefficient of interest, $\beta_{1}$, captures differential changes in deforestation after the start of the ceasefire relative to before, in municipalities with FARC presence, and in within-municipal plots characterized by $H_{c}$. This specification adds municipality/type of plot fixed effects, $\alpha_{m c}$ (that captures the average deforestation in plots of type $c$ within municipality $m$ ); municipality/time fixed effects, $\lambda_{m t}$ (so that we compare the evolution of type $c$ plots within the same municipality compared to the evolution all the other plots within that municipality); and type of plot/time fixed effects (to control for national changes per type of plot).

\section{Results}

In this section we report the results from estimating the set of regression models described above. We start with the main results and then perform a set of robustness checks and placebo exercises. We conclude the section with an analysis of the potential mechanisms behind our findings.

5.1. Main results. Table 2 summarizes the empirical estimates of the main specification (equation 4.1). Recall that our main coefficient of interest is the interaction between a (pre-ceasefire) FARC presence indicator and a time dummy that captures the period after the announcement of the permanent ceasefire.

In addition to the municipal fixed effects, column 1 controls for year fixed effects only (as opposed to department/year fixed effects). This accounts for any national shock that could affect deforestation across the board. We find that deforestation increases 
on average 0.12 percentage points on municipalities with former FARC presence after the ceasefire. This effect is economically large, as it is equivalent to 0.23 standard deviations $(=0.12 / 0.51)$.

In column 2 we estimate a more conservative specification, including, in addition to the municipal fixed effects, department/year fixed effects to account for any time shock that can affect deforestation within each department. In this way, we are comparing the change in deforestation between municipalities with and without FARC presence within the same department. We find results that are very similar -in terms of both magnitude and significance- to those reported in column 1.

To assess the validity behind our empirical strategy, that in the absence of the ceasefire the deforestation in municipalities with FARC presence would have evolved in a similar way than the deforestation in other municipalities, and at the same time get a sense of how persistent is the differential deforestation during the post ceasefire period, we present the results from estimating equation 4.2. This is a non-parametric version of the main empirical specification (equation 4.1).

The results are shown in Figure 5, where we plot the point estimates associated with the interaction of interest, together with the $95 \%$ confidence interval. Panel A shows the results with year fixed effects, while Panel B controls for department/year fixed effects. ${ }^{27}$ In neither case are there statistically significant coefficients in the years prior to the ceasefire, and the point estimates move around 0 . This supports our choice of a difference-in-differences empirical strategy. In contrast, the point estimates increase in magnitude and become significant after the start of the permanent ceasefire.

5.2. Robustness. We now present robustness to the definition of FARC presence, the measurement of deforestation, our choice of using weights by the baseline forest cover,

\footnotetext{
${ }^{27}$ Hereafter we will report results using the more conservative specification of department/year fixed. Our results are however robust to including year fixed effects only.
} 
and a placebo exercise.

In columns 1 and 2 of Table 3, we use two alternative definitions of FARC presence. We first define a municipality as having FARC presence if the number of violent attacks during the period 2011-2014 is above the 10th percentile of the empirical distribution of places with at least one event. By doing so we identify places where there was a more active involvement by FARC before the ceasefire. This measure also reduces the scope of potential measurement error. The second measure uses data from an alternative source, namely the Centro Nacional de Memoria Histórica which records all the selective killings perpetuated by FARC. ${ }^{28}$ We use a dummy that takes the value one for municipalities with at least one episode of selective killings over the period 2011-2014. Our results are robust to these alternative measures, both in terms of magnitude and significance.

In columns 3 and 4 we use two alternative measures of deforestation. The first one is equivalent to the baseline measure except that the denominator is the municipal forest coverage of the previous year, as opposed to that of 2000. The second uses an unscaled measure of deforestation, namely the log of the total area deforested (in squared kilometers) in a given year. The results using the first alternative definition of the dependent variable are remarkably similar in magnitude, but a little less precise (the p-value is 0.07 , see column 3). Using the second, we find that after the ceasefire there was an average increase in deforested area of 0.3 square kilometers (column 4).

Column 5 presents the results obtained from estimating equation 4.1 without weighting by forest coverage in 2000. This coefficient can be interpreted as the average effect of the ceasefire on deforestation across municipalities. Again, the results are very similar to the baseline estimates, both in magnitude (0.24 standard deviations) and significance.

\footnotetext{
${ }^{28}$ Selective killing is defined as an intentional homicide of up to three individuals in state of defenselessness by an illegal armed group.
} 
Finally, column 6 presents the results of a placebo exercise that uses as the treatment window the time lapsed between the beginning of the peace negotiation between FARC and the government and the declaration of the ceasefire. Our sample period for this exercise starts in 2008, and the placebo ceasefire is the period 2012-2014. If the results were mainly driven by FARC losing control of its strongholds as a result of the its engagement in a peace process (irrespective of the implementation a of a ceasefire), then we should find significant effects. Alternatively, if they respond to the deforestation incentives triggered by the ceasefire on potential investors and other economic interests, then we should find no effects during the pre-ceasefire peace negotiation period. Our findings support the latter story.

5.3. Potential mechanisms. We have established that there is a differential increase in deforestation in formerly FARC controlled areas caused by the the ceasefire. Our argument for this unintended peace-induced deforestation is that FARC's rule prevented economic activities and investments that are potentially damaging to the environment, while FARC was an active bellicose force. In this subsection we show suggestive evidence in favor of this interpretation. To that end, we estimate heterogeneous effects according to two broad type of municipal characteristics: state presence and monitoring capacity on the one hand, and economic incentives on the other. We also explore whether the observed deforestation surge has mostly taken place in small plots or else in large sections of land. Results are reported in Tables 4 and 5.

The very nature of the peace process with FARC threatens the success and sustainability of the achieved 'peace' if it is not accompanied by state-led efforts of territorial control and institutional consolidation. If the state is absent once FARC de facto withdraws from its strongholds, it should be easier for other agents to enter a municipality and engage in indiscriminate deforestation. We explore this idea formally by testing the extent to which different measures of pre-determined municipal-level state capacity 
attenuate the deforestation process in previously FARC controlled areas after the start of the ceasefire.

First, following Acemoglu et al. (2015), we use the average number of public offices in each municipality as a measure of state presence. Consistent with a story where the state can exert certain control over deforestation, we find that the increase in deforestation is offset in municipalities previously occupied by FARC, but with a higher relative state presence. Indeed, the net effect on deforestation is virtually zero in these areas (Table 4, column 1).

We can also exploit within-municipality variation in state presence using the municipal share of national parks. These are areas protected by the central government due to their environmental value and density of native as well as endangered species. Park rangers are in charge of monitoring any activity that takes place within parks' boundaries, and report to the central government anything that seems illegal or suspicious.

We estimate regression model 4.4, which includes municipality/time fixed effects so that we are comparing the change in deforestation (after the ceasefire relative to before) in national parks compared to non-national parks, within a municipality with FARC presence. This leaves us with a subsample of 198 municipalities that have both park and non-park forest areas. ${ }^{29}$ Consistent with our hypothesis that national parks should attenuate the process of increased deforestation after the ceasefire, via more state presence, we find that deforestation in national parks is lower compared to that in non-national park areas, in FARC controlled municipalities after the ceasefire (Table 5, column 1).

In contrast, using the log distance to military units as a measure of military presence, we find that FARC areas that are further away from them experience a lower increase in deforestation (Table 4, column 2). This is consistent with the idea that the role

\footnotetext{
${ }^{29}$ In this restricted sample there are 30 municipalities previously occupied by FARC.
} 
of state forces is not to oversee potentially damaging economic activities, but rather to protect investors from extortion and ransom carried out by illegal armed groups. Thus, while more state presence (in the form of a variety of executive and judicial institutions, as well as public servants) can put a check on deforestation, higher military presence can (perhaps unintentionally) exacerbate it by providing a more secure business environment.

In terms of the economic incentives that may exacerbate the deforestation effects of the ceasefire, we explore the role of livestock grazing and coca cultivation. Recall that, according to FAO, cattle ranching is the main source of deforestation in Latin America since the 1990s (see section 3). Consistently, we find that the increase in deforestation in places that witnessed cattle ranching prior to the ceasefire is significantly higher after the start of the ceasefire in areas that had FARC presence (Table 4, column 3).

As for coca growing, we use a measure of municipal-level coca suitability. This index was created by Mejıa and Restrepo (2015) based on municipal soil and climate characteristics. We find no differential effect based on coca suitability, and if anything we obtain a negative sign for the estimated coefficient of the three-way interaction: there is less deforestation in municipalities more suitable for coca cultivation (Table 4, column 4). This is consistent with coca growing being less land intensive and occurring mainly in smaller plots.

Table 5 provides further evidence that the observed deforestation rise seems to be driven by "massive" (as opposed to "granular") deforestation patterns, as defined in section 3. Massive deforestation is consistent with economic activities that are relatively more land intensive, such as large agricultural plantations (e.g. oil palm) or pasturage for grazing. Instead, granular deforestation is consistent with smaller-scale activities such as subsistence agriculture or coca growing. 
We test whether our results are driven by either massive or granular deforestation by estimating equation 4.4. The results, reported on columns 2 to 4 of Table 5, suggest that, after the ceasefire, the municipalities with FARC presence experienced a differential increase in massive deforestation. ${ }^{30}$

Overall, this subsection provides robust evidence consistent with deforestation incentives being attenuated by state presence and monitoring, and exacerbated by military protection and cattle ranching. They also show that peace-induced deforestation is likely explained by land intensive economic activities taking place in former FARC strongholds.

\section{Conclusions}

This paper uses Colombia as a case study to investigate the effect of conflict on deforestation. We do so indirectly, by studying how the recent peace process affected deforestation in conflict-affected areas. Armed conflict can contribute to environmental damage through several channels including direct predation from fighting groups, but may also help preserve ecosystems by dissuading extractive economic activities from conflict areas. Our results support the latter mechanism.

Our main finding is that the de facto withdrawal of FARC from its controlled territories in the context of the permanent ceasefire announced on December 2014, generated economic incentives that ultimately increased deforestation in areas with FARC presence. Importantly, we show that these incentives are exacerbated by the prior existence of cattle ranching and the proximity to military bases, and attenuated by (non-military) state capacity and monitoring. We also show that the magnitude of deforestation is not compatible with the development of small scale agriculture (including coca growing)

\footnotetext{
${ }^{30}$ The differences in sample size from columns 2 to 4 is due to the fact that only municipalities with both massive and granular deforestation are included in the regression sample.
} 
but rather with extensive economic activities.

These results highlight the importance of complementing peacemaking milestones with state building efforts and good governance to avoid environmental impacts. This is by and large the main policy implication of the paper. Future work could focus on evaluating policies to achieve sustainable development in areas previously disconnected from markets due to violence. 


\section{REFERENCES}

Acemoglu, D., C. Garcia-Jimeno, and J. A. Robinson (2015): "State capacity and economic development: A network approach," American Economic Review, 105, 2364-2409.

Acemoglu, D., J. A. Robinson, and R. J. Santos (2013): "The monopoly of violence: Evidence from colombia," Journal of the European Economic Association, 11, 5-44.

Arjona, A. M. And L. OtÁlora (2011): "Presencia vs. violencia: problemas de medición de la presencia de actores armados en Colombia," Foco Económico.

Auty, R. (1993): Sustaining Development in Mineral Economies: The Resource Curse Thesis, Routledge.

Besley, T. And T. Persson (2014): "The causes and consequences of development clusters: State capacity, peace, and income," Annu. Rev. Econ., 6, 927-949.

Burgess, R., M. Hansen, B. A. Olken, P. Potapov, And S. Sieber (2012): "The Political Economy of Deforestation in the Tropics," The Quarterly Journal of Economics.

Burgess, R., E. Miguel, And C. Stanton (2015): "War and deforestation in Sierra Leone," Environmental Research Letters, 10, 095014.

Camacho, A. And C. Rodriguez (2013): "Firm Exit and Armed Conflict in Colombia," Journal of Conflict Resolution, 57, 89-116.

CERAC (2016): "Un año de desescalamiento: conflicto casi detenido, pero que se resiste a desaparecer," 12.

Ch, R., A. Steele, J. Shapiro, and J. Vargas (2018): "State capacity and economic development: A network approach," American Political Science Review, 112.

CIFOR (2018): "Forests and conflict," Tech. rep., Center for International Forestry Research.

DÁvalos, L. M. (2001): "The San Lucas mountain range in Colombia: how much conservation is owed to the violence?" Biodiversity \& Conservation, 10, 69-78.

Dell, M., B. F. Jones, And B. A. Olken (2014): "What do we learn from the weather? The new climate-economy literature," Journal of Economic Literature, 52, 740-98.

Etter, A., C. McAlpine, S. Phinn, D. Pullar, and H. Possingham (2006): "Unplanned land clearing of Colombian rainforests: Spreading like disease?" Landscape and Urban Planning, 77, 240-254.

Fearon, J. And D. Laitin (2003): "Ethnicity, Insurgency, and Civil War," American Political Science Review, 97, 75-90.

Fergusson, L., D. Romero, And J. VArgas (2014): "The environmental impact of civil conflict: the deforestation effect of paramilitary expansion in Colombia," .

Fergusson, L., J. F. Vargas, And M. Vela (2018): "Sunlight Disinfects? Free Media in Weak Democracies," Working paper Universidad El Rosario.

Hansen, M. C., P. V. Potapov, R. Moore, M. Hancher, S. A. Turubanova, A. Tyukavina, D. Thau, S. V. Stehman, S. J. Goetz, T. R. Loveland, A. Kommareddy, A. Egorov, L. Chini, C. O. Justice, And J. R. G. Townshend (2013): "High-Resolution Global Maps of 21st-Century Forest Cover Change," Science, 342, 850-853.

Mejia, D. And P. Restrepo (2015): "Bushes and Bullets: Illegal Cocaine Markets and Violence in Colombia." .

Ministerio de Ambiente (2017): "Estrategia Integral de Control a la Deforestación y Gestión de los Bosques," Tech. rep.

Prem, M., A. Rivera, D. Romero, and J. F. VArgas (2018): "Killing Social Leaders for Territorial Control: The Unintended Consequences of Peace," Documentos de Trabajo Universidad del Rosario No. 016385.

Restrepo, J., M. Spagat, And J. Vargas (2004): "The dynamics of the columbian civil conflict: A new dataset." Homo Oeconomicus, 21, 396-429.

Richani, N. (1997): "The Political Economy of Violence: The War-System in Colombia." Journal of Interamerican Studies and World Affairs, 39, 37-81. 
Ross, M. (2012): The Oil Curse: How Petroleum Wealth Shapes the Development of Nations, Princeton University Press.

Saavedra, S. And M. Romero (2018): "Communal Property Rights and Deforestation: Evidence From Colombia," .

Seymour, F. And J. Busch (2016): Why forests? Why now?: The science, economics, and politics of tropical forests and climate change, Brookings Institution Press.

UNODC (2016): "Monitoreo de territorios afectados por cultivos ilícitos 2015," Tech. rep.

YePes, A. AND J. GonzÁlez (2018): "Caracterización de las principales causas y agentes de la deforestación a nivel nacional período 2005-2015," Tech. rep., Instituto de Hidrología, Meteorología y Estudios Ambientales - IDEAM. Ministerio de Ambiente y Desarrollo Sostenible. Programa ONU-REDD Colombia. 
FiguRE 1. Forest cover and deforestation hotspots

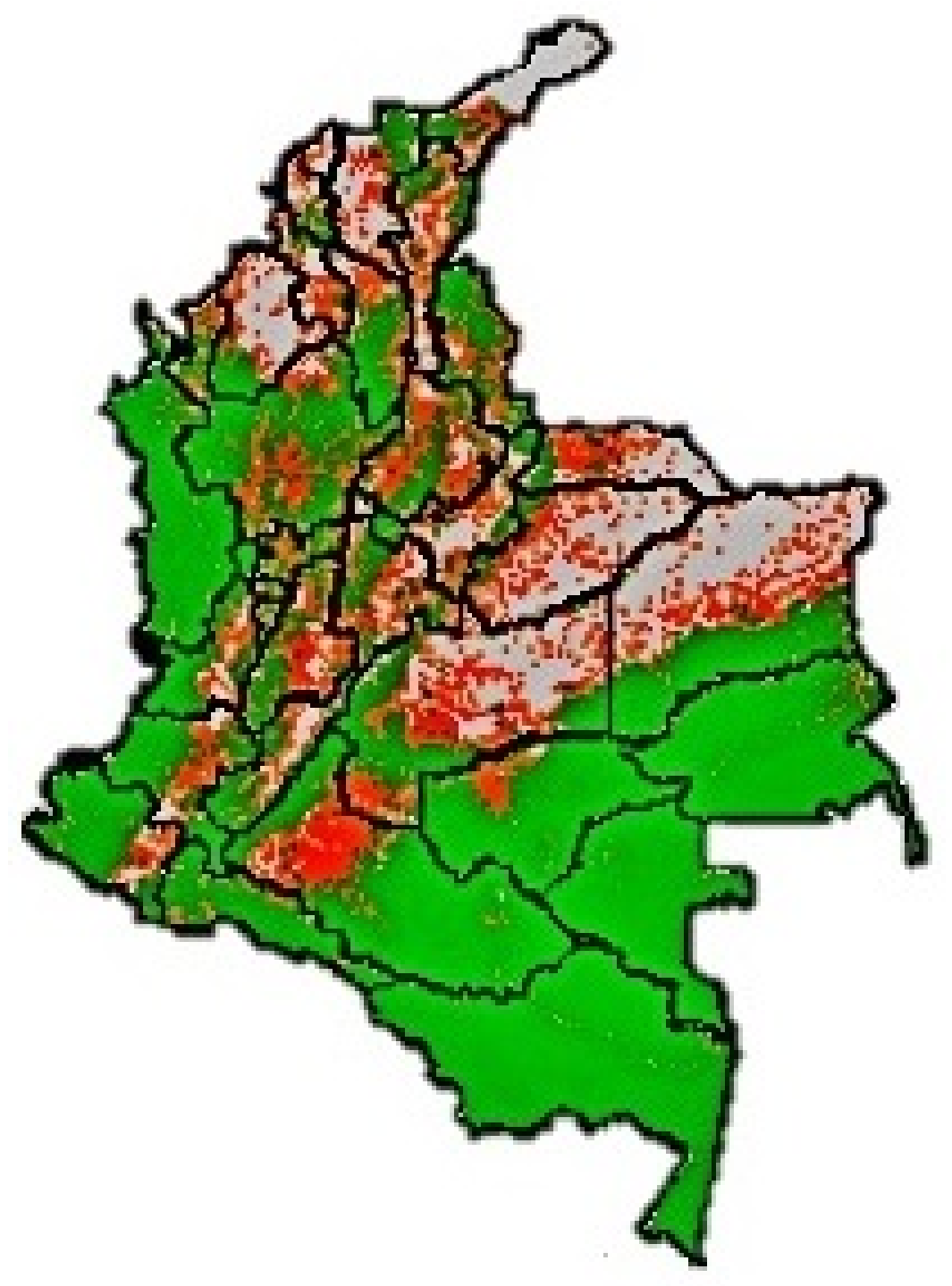

Notes: Areas on green represent forest cover, while areas on red represent deforestation. Source: Global Forest Change 
Figure 2. Definition of granular and massive deforestation

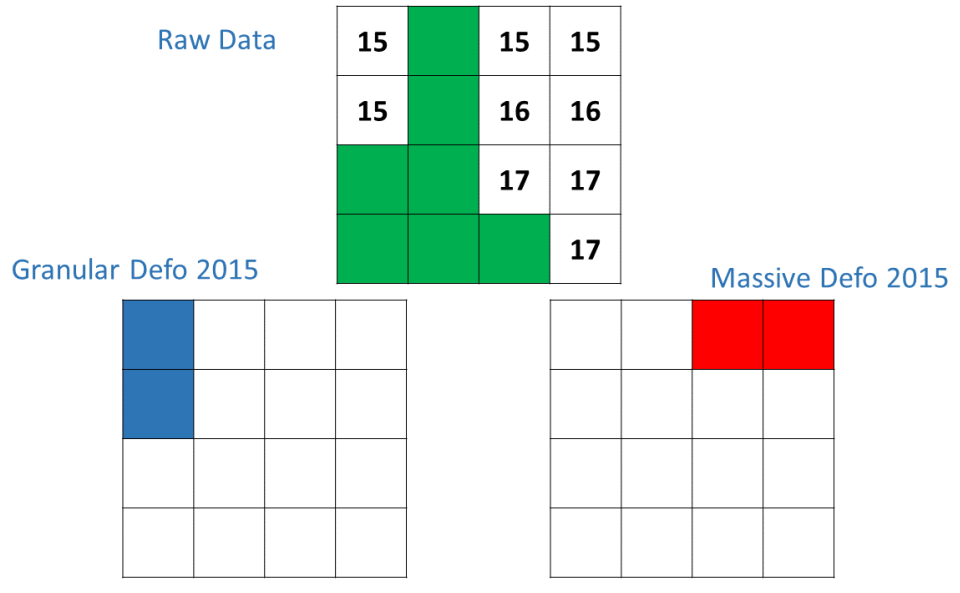

Notes: The raw data (top grid) indicate the year in which each pixel (square) was deforested. We aggregate contiguous deforested pixels, as measured in 2017, into deforested polygons. With the area of these polygons we define granular and massive deforestation each year. In the figure above, for the year 2015, even though both patches of deforestation are of two pixels (bottom grids), the one on the left is granular and the one on the right is massive. This because the neighboring pixels of the one on the left are not deforested later, and the polygon does not add to 1 hectare. The one on the right, on the other hand, keeps growing through the sample period, reaching 12 pixels of $30 m \times 30 m>1$ hectare. 
Figure 3. Cumulative deforested area in Colombia, 2015-2017.

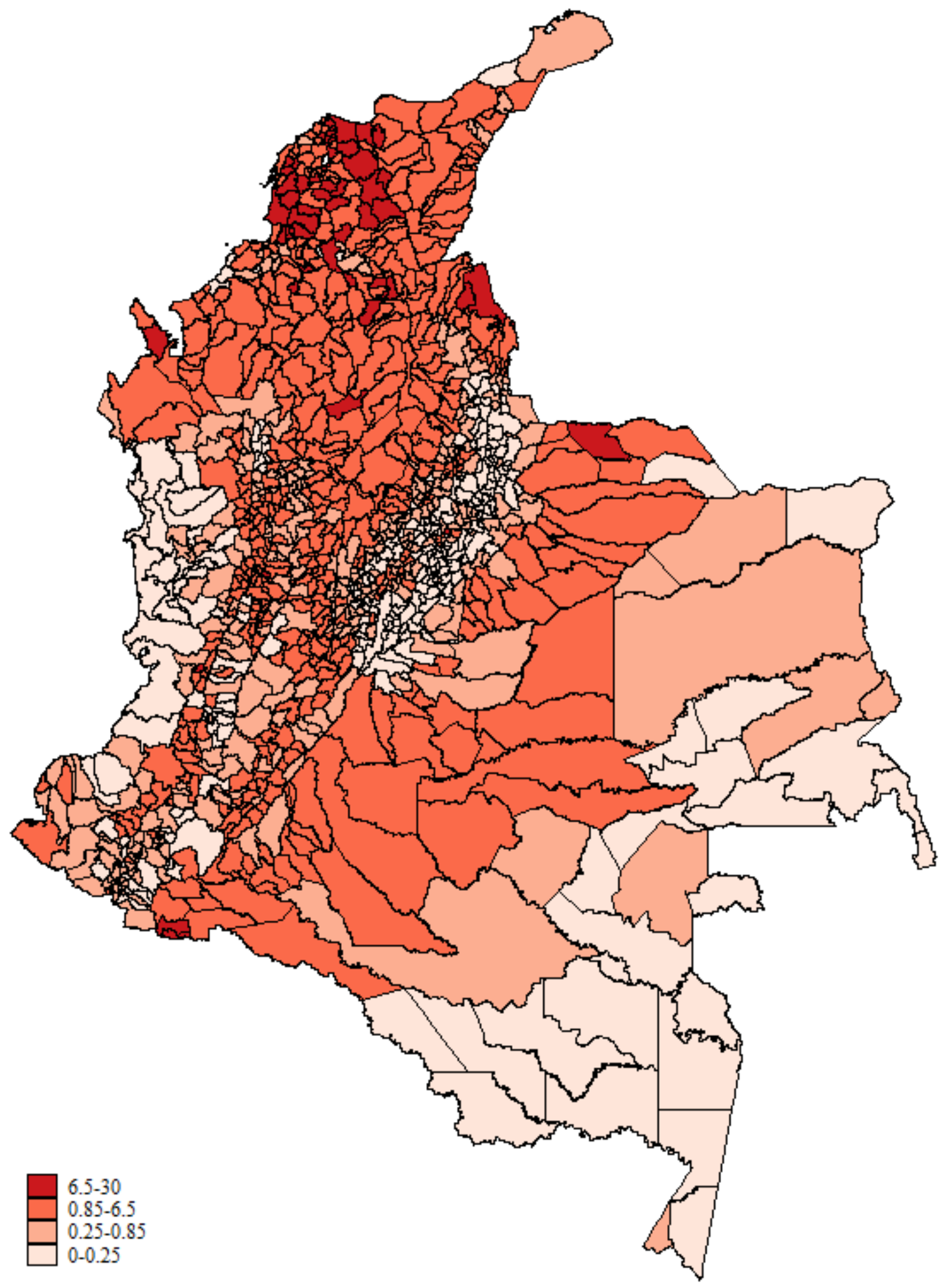

Notes: This map presents the spatial distribution of deforestation after the ceasefire (2015-2017). 
FiguRE 4. Evolution of deforestation

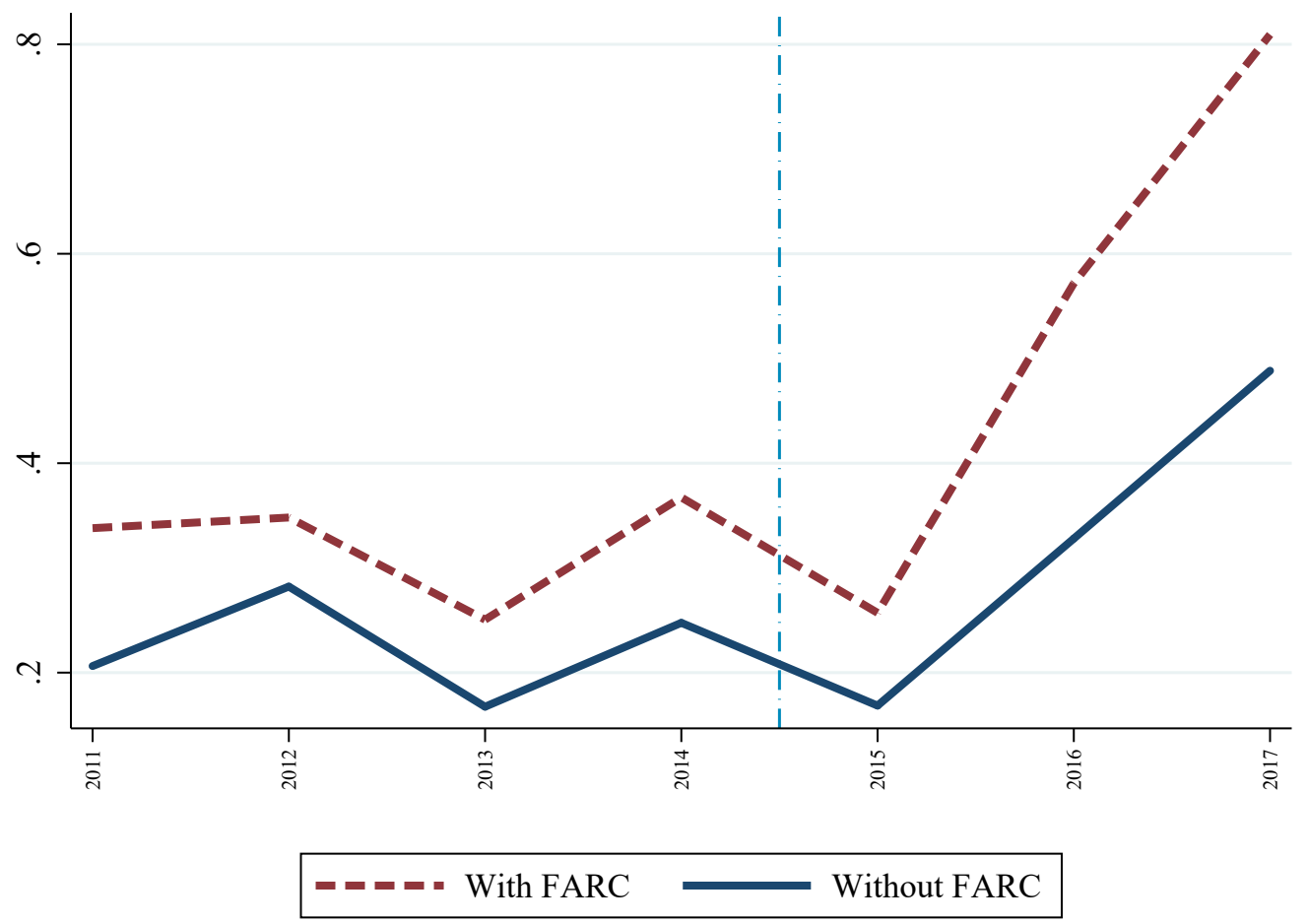

Notes: This figure presents the evolution of the deforested area, as a share of forest coverage, from 2011 to 2017. We split the sample by type of municipality into those with FARC presence and those without FARC presence. 
Figure 5. Dynamic difference-in-differences

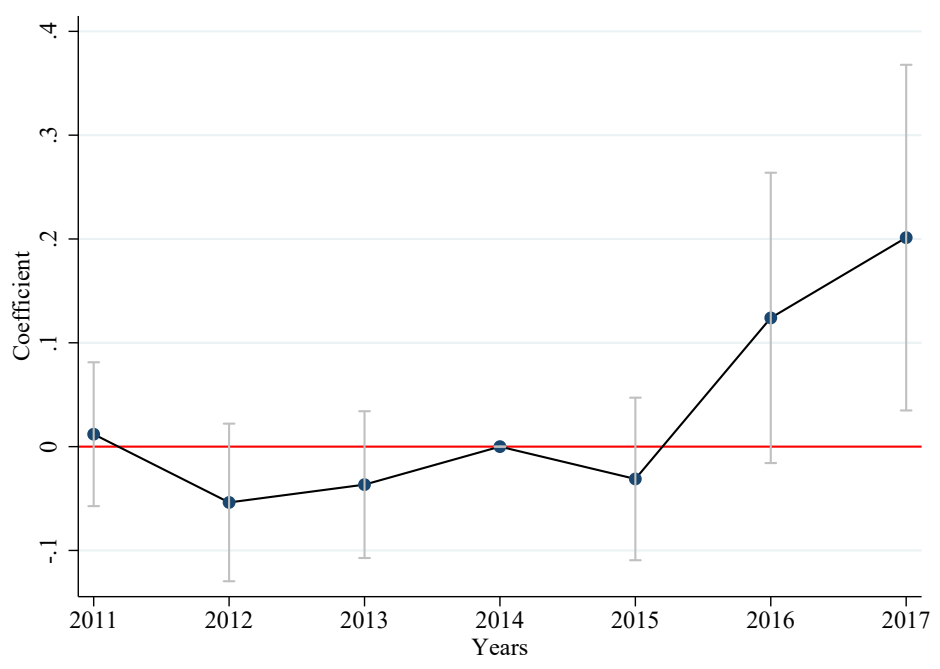

A.

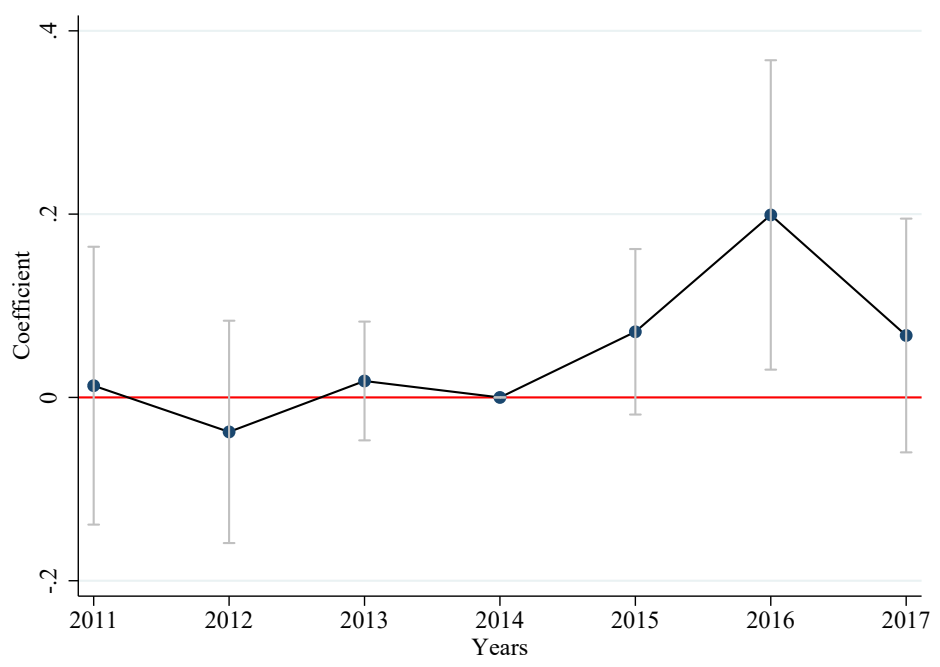

B.

Notes: This figure presents the coefficients from our dynamic difference-in-differences specification presented in equation (4.2). Panel A includes year fixed effects, while panel B includes department/year fixed effects. We present the point estimates of the regressions and the confidence interval at the $95 \%$. 
END-OF-CONFLICT DEFORESTATION

TABLE 1. Summary statistics

\begin{tabular}{|c|c|c|c|}
\hline & $\begin{array}{c}(1) \\
\text { Mean }\end{array}$ & $\begin{array}{c}(2) \\
\text { Std. Dev. }\end{array}$ & $\begin{array}{c}(3) \\
\text { Median }\end{array}$ \\
\hline$\%$ forest area on 2000 & 51.63 & 26.08 & 53.46 \\
\hline$\%$ deforested area over forest coverage on 2000 & 0.50 & 0.54 & 0.33 \\
\hline$\%$ deforested area over forest net coverage & 0.56 & 0.77 & 0.35 \\
\hline FARC presence & 0.12 & 0.32 & 0.00 \\
\hline State presence Index & 13.51 & 2.51 & 13.00 \\
\hline Log of distance to closest military unit & 0.66 & 1.54 & 0.65 \\
\hline Cattle per hectare & 44.01 & 35.41 & 36.22 \\
\hline Coca suitability Index & 0.09 & 0.72 & 0.07 \\
\hline
\end{tabular}

Notes: This table presents summary statistics for the main variables of interest used in the analysis. An observation is a municipality except the variables on $\%$ deforested area that refer to municiaplity-year. 
TABLE 2. Deforestation and ceasefire

\begin{tabular}{lcc}
\hline \hline & $(1)$ & $(2)$ \\
Cease × FARC & $\begin{array}{c}0.12^{* *} \\
(0.05)\end{array}$ & $\begin{array}{c}0.11^{* *} \\
(0.06)\end{array}$ \\
& & \\
Mean. Dep. Var. & 0.31 & 0.31 \\
Std. Dev. Dep. Var. & 0.51 & 0.51 \\
Municipalities & 1,118 & 1,118 \\
Observations & 7,826 & 7,826 \\
R $^{2}$ & 0.62 & 0.72 \\
Municipality FE & Yes & Yes \\
Year FE & Yes & No \\
Department/Year FE & No & Yes \\
\hline \hline
\end{tabular}

Notes: This table presents the results from the main specification in equation (4.1). The dependent variable is the share of deforested area over forest coverage in 2000. Cease is a dummy that takes the value one for the period after 2014. FARC is a dummy for those municipalities with FARC presence defined using any attacks. All regressions are weighted by forest coverage in the municipality in 2000. Clustered robust standard error at the municipality level in parenthesis, $* p<0.10$, $* * p<0.05$, $* * * p<0.01$. 


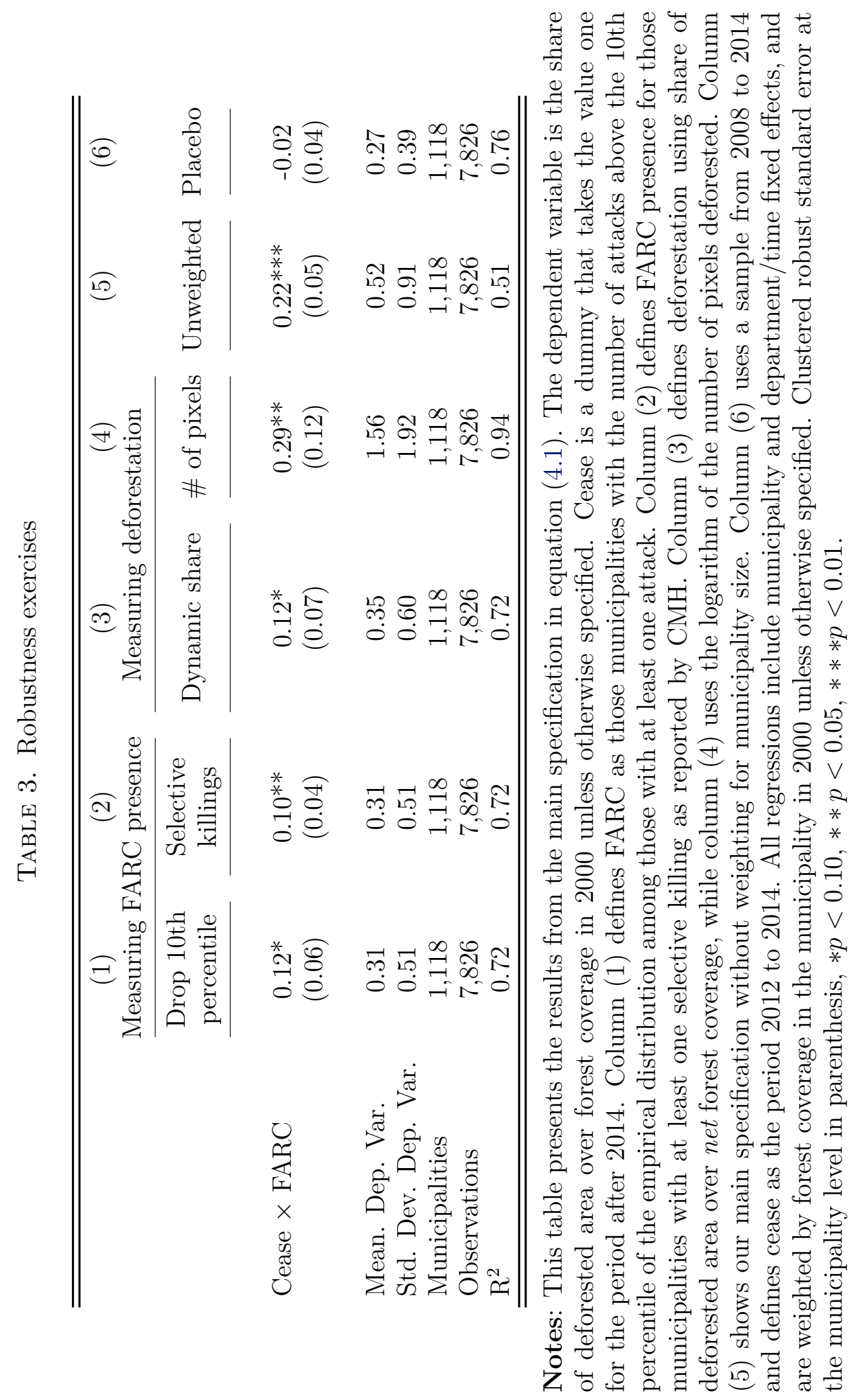


TABLE 4. Heterogeneous effects by municipality characteristics

\begin{tabular}{|c|c|c|c|c|}
\hline & $\begin{array}{c}(1) \\
\text { State presence }\end{array}$ & $\begin{array}{l}(2) \\
\text { Dist. to military }\end{array}$ & $\begin{array}{c}(3) \\
\text { Cattle }\end{array}$ & $\begin{array}{c}(4) \\
\text { Coca suitability }\end{array}$ \\
\hline Cease $\times$ FARC $\times Z$ & $\begin{array}{c}-0.23^{* * *} \\
(0.06)\end{array}$ & $\begin{array}{c}-0.04^{*} \\
(0.10)\end{array}$ & $\begin{array}{c}0.36^{* * *} \\
(0.14)\end{array}$ & $\begin{array}{l}-0.18 \\
(0.13)\end{array}$ \\
\hline Cease $\times$ FARC & $\begin{array}{c}0.25^{* * *} \\
(0.06)\end{array}$ & $\begin{array}{c}0.13^{* *} \\
(0.05)\end{array}$ & $\begin{array}{c}0.04 \\
(0.05)\end{array}$ & $\begin{array}{c}0.24^{* *} \\
(0.12)\end{array}$ \\
\hline Cease $\times Z$ & $\begin{array}{c}0.01 \\
(0.02)\end{array}$ & $\begin{array}{c}0.02^{* *} \\
(0.01)\end{array}$ & $\begin{array}{c}-0.10^{* *} \\
(0.04)\end{array}$ & $\begin{array}{c}0.05^{* *} \\
(0.03)\end{array}$ \\
\hline Mean. Dep. Var. & 0.31 & 0.31 & 0.31 & 0.31 \\
\hline Std. Dev. Dep. Var & 0.51 & 0.51 & 0.51 & 0.51 \\
\hline Municipalities & 1,118 & 1,118 & 1,118 & 1,118 \\
\hline Observations & 7,826 & 7,826 & 7,826 & 7,826 \\
\hline $\mathrm{R}^{2}$ & 0.72 & 0.72 & 0.72 & 0.72 \\
\hline
\end{tabular}

Notes: This table presents the results from equation (4.3). The dependent variable is the share of deforested area over forest coverage in 2000. Cease is a dummy that takes the value one for the period after 2014. FARC is a dummy for those municipalities with FARC presence using any attacks. State presence is a dummy for those municipalities with the index of state presence above the median of the distribution (Acemoglu et al., 2015). Military presence is defined as the logarithm of the distance to the closest military unit. Cattle is a dummy for the number of catlle ranching per hectare being avobe the median of the empirical distribution. Coca suitability is a dummy for those municipalities with the index of coca suitability from Mejia and Restrepo (2015) above the median of the empirical distribution. All regressions include municipality and department/year fixed effects, and all are weighted by forest coverage in the municipality in 2000. Clustered robust standard error at the municipality level in parenthesis, $* p<0.10, * * p<0.05, * * * p<0.01$. 
TABLE 5. Within municpality heterogeneous effects

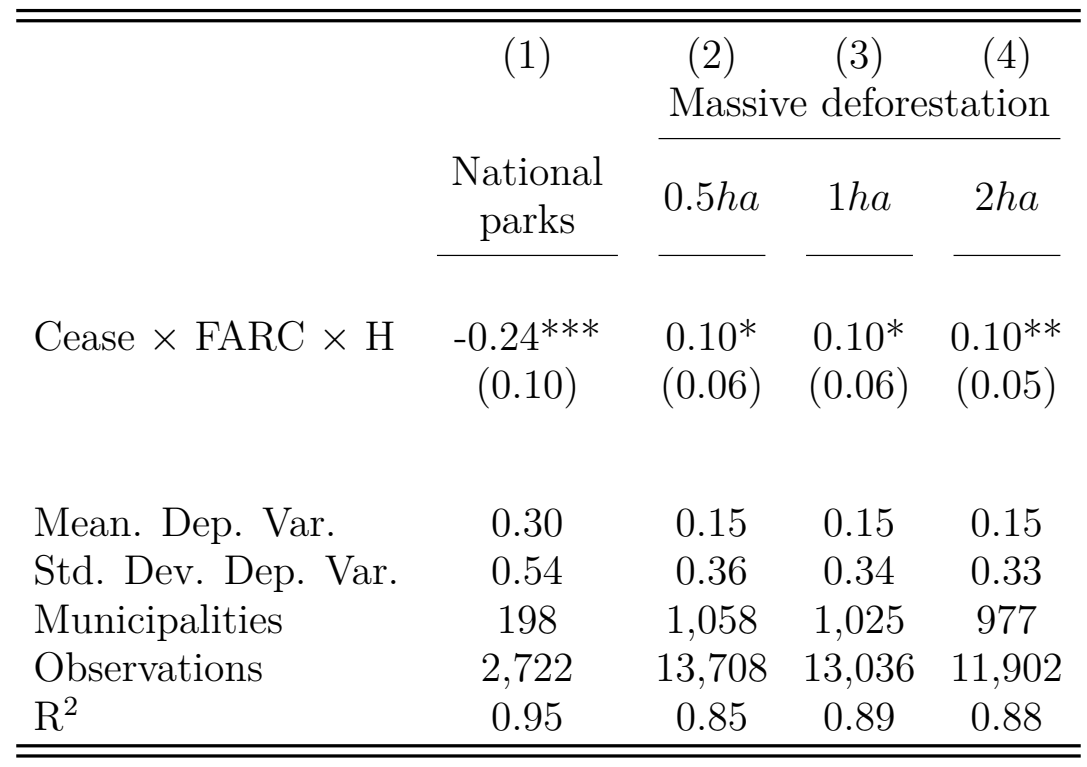

Notes: This table presents the results from equation (4.4). The dependent variable is the share of deforested area by type over forest coverage in 2000. Cease is a dummy that takes the value one for the period after 2014. FARC is a dummy for those municipalities with FARC presence using any attacks. National parks splits the municipality into national parks and other lands. Massive deforestation splits deforestation into massive and granular as discussed in 3 for different cutoffs. All regressions include municipalityyear, municipality-type and type-year fixed effects. Both columns are weighted by forest coverage in the municipality in 2000. Clustered robust standard error at the municipality level in parenthesis, $* p<0.10, * * p<0.05, * * * p<0.01$. 